УДК 94:355.1(100)

ЧОБІТ I.P.

https://orcid.org/0000-0001-6669-2474

https://doi.org/10.33577/2313-5603.31.2019.179-192

\title{
ІСТОРИЧНИЙ ДОСВІД ПРОВІДНИХ КРАЇН СВІТУ У ЗАПРОВАДЖЕННІ ТА ФУНКЦІОНУВАННІ СТРУКТУР ЦИВІЛЬНО-ВІЙСЬКОВОГО СПІВРОБІТНИЦТВА (СІМІС)
}

У статті коротко розкрито історію створення та функціонування структур Civil-Millitary Cooperation (далі - CIMIC) в арміях провідних країн світу. Обгрунтовано концепції цивільно-військового співробітництва (далі - ЦВС) у нормативно-правових актах оборонної стратегії США та ряду країн Свропи. Показано необхідність розуміння концепції CIMIC в умовах військової діяльності, що спрямована на реконструкцію та модернізацію збройних сил у напрямі тісного зв'язку із цивільною стороною. Висвітлено роль ЦВС як механізму, який дозволяє створити передумови для вирішення поставлених задач, надання відповідної допомоги цивільному населенню та успішного завершення збройного конфлікту.

Ключові слова: цивільно-військове співробітництво, доктрина, СІМІС, НАТО, збройні сили.

Постановка проблеми та стан ї̈ дослідження. Упродовж останніх років змінилися підходи до врегулювання конфліктів та були суттєво переглянуті правові вимоги щодо до їх учасників. Міжнародна спільнота підвищує вимоги до врахування економічних, соціальних, релігійних, політичних, культурних і гуманітарних факторів під час планування та проведення міжнародних миротворчих операцій. Як показує міжнародний досвід, залучення широкого кола цивільних інституцій у процес вирішення існуючого конфлікту сприяє досягненню спільної мети - врегулювання цього збройного конфлікту.

Актуальність дослідження ЦВС, насамперед, зумовлена збройним конфліктом на Сході України. Система ЦВС в Збройних Силах України є порівняно новою та постійно вдосконалюється. Теоретичний та практичний інтерес складає саме функціонування таких структур в арміях іноземних держав, їх особливості та відмінності від української системи ЦВС.

Чобіт Іванна Романівна, ад’юнкт Національної академії сухопутних військ імені гетьмана Петра Сагайдачного, м. Львів.

(C) Чобіт I.P., 2019 
Вітчизняні дослідники вже звертали певну увагу на проблематику військово-цивільного співробітництва, досліджуючи інформаційне забезпечення, систему підготовки фахівців цивільно-військової співпраці та цивільно-військові відносини в країнах НАТО. Варто відзначити статті Ю. Калагіна, І. Коропатніка, С. Гаркуші, Н. Васюкової, Е. Тітко, П. Ткачука, В. Опришко, І. Куропаткіна, О. Ноздрачова, О. Лещенко, а також низку колективних робіт. Проте діяльність системи цивільно-військового співробітництва провідних країн світу досліджена не повністю.

Метою статті $\epsilon$ аналіз регулювання діяльності структури цивільно-військового співробітництва провідних країн світу із поясненням основних принципів та завдань, де особлива увага звертається на елемент зв'язку із цивільним елементом.

Виклад основного матеріалу. Після завершення Другої світової війни у світовій спільноті з'явився новий етап воєнно-політичних конфліктів, особливістю яких є пріоритет використання противниками широкого спектра невоєнних чинників - економічних, інформаційних, екологічних, соціальних та політичних важелів впливу. 3 огляду на це такі конфлікти називають «гібридними війнами». Головним завданням «гібридної війни» $є$ не стільки фізичне знищення збройних сил противника, скільки нав'язування агресором своєї ідеології населенню держави, з якою йде протистояння. Тобто у війнах «гібридного типу» цивільне населення не тільки несе основний фізичний та психологічний тягар наслідків збройного протистояння (загроза життю та здоров'ю, порушення умов життєдіяльності), але й знаходиться під шаленим тиском інформаційної та психологічної складової воєнно-політичного конфлікту. Саме тому у 90-х роках XX ст., у зв'язку із численними міжетнічними конфліктами на територіях країн Південної та Східної Свропи, для врегулювання яких залучалися міжнародні миротворчі контингенти, в органах військового управління збройних сил країн НАТО виникла потреба у створенні структур, які б працювали із цивільним населенням. Власне, на основі досвіду операцій на території колишньої Югославії було зроблено висновок, що застосування військових засобів вже не є вирішальним фактором для досягнення кінцевої мети. Наявні виклики і загрози потребували всебічного вивчення місцевого населення та впливу громадянського суспільства на дії військових багатонаціональних груп. 
Саме цивільно-військове співробітництво забезпечувало ефективне проведення таких заходів. Термін CIMIC почав використовуватися з початку 1990-х років (Ткачук та ін., 2018). Досвід збройних сил США послугував основою для впровадження концепції, що стосувалася цивільно-військового співробітництва (далі - ЦВС) в рамках НАТО. Адже у Північному Іраку (1991 р.), Сомалі (1993 1994 рр.) та Руанді (1994 р.) функціонували центри, котрі слугували пунктами зустрічі представників місцевої влади, міжнародних організацій та представників збройних сил, урядових служб США для вирішення проблемних питань та координації 3 надання гуманітарної допомоги. Певної структури для таких центрів не було визначено. Їх розмір і склад залежав від конкретної ситуації та потреб (Civil - Military Cooperation Centre of Excellence, 2016). Після узагальнення досвіду участі у військових операціях в різних куточках світу в арміях провідних країн та НАТО розпочалась розробка нормативно-правових документів, що стосувалися цивільновійськової співпраці. У 1992 р. НАТО прийняло рішення про участь в миротворчих операціях ОБСЄ і ООН, до яких почали залучати невійськових учасників. 3 кінця 1995 р. розпочалась реалізація концепції цивільно-військової взаємодії НАТО, яка була пов'язана iз врегулюванням ситуації у Боснії і Герцеговині (Тітко, 2017b). У серпні 1997 р. був прийнятий перший документ, що стосувався CIMIC, - Військова політика НАTO CIMIC MC 411 (NATO Military Policy on Civil-Military Cooperation) та доопрацьований i прийнятий як MC 411/1 у 2001 р. (North Atlantic Treaty Organization, 2003). У цій директиві Військового комітету НАТО говорилося, що ЦВС - це військова структура, основним завданням якої $є$ підтримка цивільних органів влади, місцевого населення, урядових та міжнародних організацій, що забезпечить успішне виконання завдань при застосуванні військ під час проведення міжнародних операцій $з$ підтримки миру та безпеки. Відповідно до МС 411 передбачалося створення робочої групи НАТО, роль якої полягала у повноцінному залученні структур ЦВС до Об'єднаного командування Європи до 2000 р. Також вказувалось, що оперативні командири повинні розглядати CIMIC як складову частину процесу планування для проведення будь-якої операції та залежно від ії типу розміщувати підрозділи СІМІC (Тітко, 2017b). У 2003 р. було розроблено суттєвий документ ЦВС НАТО - Доктрину СІМІС НАТО АЈР-9. Відповідно до доктрини НАТО система ЦВС під час 
операцій під егідою НАТО повинна: ставити в пріоритет військові цілі і завдання; підтримувати систему керівництва і контролю на всіх рівнях; бути економною, а саме мінімально використовувати військові ресурси при максимальному використанні цивільних, до того ж важливо не допустити виснаження останніх, оскільки це негативно вплине на підтримку життєдіяльності місцевого населення; концентрувати увагу на нечисленних, але об'ємних пріоритетних проектах, та дотримуватись зобов'язань, визначених міжнародним гуманітарним правом (Rietjens, 2008).

Для ЦВС в операціях з підтримки миру та безпеки додатково застосовуються ще й такі принципи: визначення спільної мети, завдання та сфер впливу для військових і цивільних учасників операції; розподіл відповідальності за успішну чи неуспішну діяльність між військовими і цивільними структурами; налагодження чіткої системи зв'язку і координації між учасниками операції; прозорість дій; обізнаність $з$ місцевою культурою, звичаями та традиціями (НУОУ ім. Івана Черняховського, 2015).

У 2008 р. через чергову трансформацію Північноатлантичного альянсу у штабі Верховного головнокомандувача Об'єднаних збройних сил НАТО у Свропі була переглянута та доопрацьована Доктрина AJP-9 із залученням робочої групи з Чеської Республіки, Данії, Німеччини, Нідерландів, Норвегії та Польщі. Вже у лютому 2013 р. був прийнятий оновлений документ AJP-3.4.9, в якому врахована необхідність адаптації до сучасних викликів та вимог, а також внесені необхідні зміни у бачення ЦВС на основі набутого нового досвіду у веденні військових конфліктів (Rietjens, 2008). У документі визначені загальні положення, що стосуються гуманітарної допомоги та розвитку: цілі гуманітарної допомоги та розвитку, що полягають у спільній роботі щодо внеску у покращення якості життя людини; недискримінація, що вказує на надання допомоги виключно на основі визначених потреб, незалежно від розташування, етнічної приналежності, статі, соціального статусу або релігії; повага до людської гідності, яка реалізовується відповідно до принципів та норм міжнародного права, яка також включає в себе повагу культури, релігії та звичаїв; прозорість та підзвітність, що полягають у тому, що, здійснюючи допомогу, варто переконатись у відсутності корупції, крадіжки або зловживання ситуацією; стійкість і готовність полягають у заходах, які реалізовуються з урахуванням місцевих умов і спрямовані на зміцнення 
місцевих ресурсів за рахунок укріплення громадянського суспільства, органів місцевого самоврядування до поточних потреб; координація, мається на увазі діяльність 3 урядом і зацікавленими суб'єктами на кожному рівні. Особлива роль у АJP-3.4.9 відводиться співпраці CIMIC із неурядовими організаціями (NATO, 2003). Сьогодні союз НАТО обрав шлях врегулювання кризових ситуацій через призму цивільно-військової співпраці, адже які б не були поставлені задачі, вони виконуються у цивільному середовищі, де плідна взаємодія із мирним населенням є чи не найважливішим аспектом для швидкого вирішення конфлікту.

В армії США весь особовий склад, який перебуває на дійсній службі або в резерві, отримує необхідну підготовку для підтримки цивільно-військових операцій та здійснення взаємодії із цивільним населенням. У Доктрині СІМІС США цивільно-військові операції (далі - ЦВО) розуміють як діяльність командира 3 метою налагодження, підтримання відносин, здійснення впливу чи прагматичного використання стосунків між військовими, урядовими та неурядовими цивільними організаціями, представниками влади, цивільним населенням та території проведення операції з позитивним, нейтральним або ворожим ставленням до військової присутності. Така діяльність здійснюється для полегшення воєнних операцій, консолідації зусиль та досягнення оперативних цілей США. Цивільновійськова операція здійснюється визначними цивільними і військовими представниками або в поєднанні цих двох компонентів. Доктрина CIMIC HATO та Доктрина CIMIC США дещо схожі між собою, адже у Доктрині НАТО використаний досвід США в миротворчих операціях. Проте існує і певна відмінність між ними. НАТО вбачає у ЦВС можливість покращення координації з цивільним компонентом. Доктрина НАТО не зосереджена суто на проведенні проектів, хоча здійснення гуманітарних проектів на підтримку своїх також не виключається. Підхід США зосереджується на здійсненні впливу на цивільне оточення з метою підтримки своїх сил. Військовослужбовці збройних сил США під час ЦВО можуть виконувати функції цивільних органів влади та організацій, тобто принцип США передбачає певне пристосування до потреб військових. Також цікавим є той факт, що фахівці ЦВС входять до відділу вогневого ураження. А командир перед тим, як прийняти рішення щодо вогневого ураження, запитує у представників ЦВС: чи $є$ можливість вирішити цю проблему шляхом залучення ЦВС, а 
саме досягти прихильності місцевого населення, щоб вони не сприяли незаконним збройним формуванням (Rietjens, 2008).

Національні доктрини ЦВС різних держав базуються та розробляються відповідно до норм власного національного законодавства, внутрішніх національно-стратегічних орієнтирів та на основі Доктрини НАTO AJP-9 (Tіmко, 2017a). Наприклад, у доктрині Республіки Хорватія сказано, що сучасна теорія військово-цивільних відносин пов'язана з розподілом сторін, де одна сторона є громадянське суспільство, інша - збройні сили. Починаючи 3 2000-х років, уряд Хорватії активізував свою діяльність щодо реформування цивільних i військових відносин. Звичайно, були певні труднощі: необхідність реалізації оборонних реформ у контексті цивільно-військового співробітництва, відсутність досвіду цивільної та військової оборони та необхідність скоротити витрати на оборону із загального бюджету із подальшою модернізацією збройних сил. Доктрина ЦВС збройних сил Хорватії базується на Доктрині AJP-9 НАТО і розглядається як загальні стандарти для здійснення діяльності збройними силами Хорватії. Сьогодні у Хорватії відбувається процес оновлення доктрини АJP-9 до нового стандарту НАТО АЈР-3.4.9 (Лещенко, 2017). Загалом розвиток системи ЦВС в Хорватії пов'язаний із реформуванням збройних сил до стандартів НАТО.

У збройних силах Королівства Данії система СIMIC функціонує також за стандартами НАТО. Найширше вони застосовували ЦВС під час операцій у боротьбі із повстанцями в Афганістані. ЦВС у Данії являє собою співробітництво, що спрямоване на підтримку операцій військового командира, особливо в операціях щодо стабілізації обстановки, де основним завданням командира $є$ взаємодія із місцевою владою та населенням на території проведення місії. Також фахівці СІМІС виступають у ролі радників із цивільних питань. Відповідно до Доктрини Данії, ЦВС є військовим елементом, який пов'язує громадянське суспільство із військовими та розглядається як форма взаємодії для досягнення поставлених цілей (Rietjens, 2008). Тому в пріоритеті CIMIC є підтримка військових в районі виконання завдань та взаємодія із цивільною владою, міжнародними урядовими та неурядовими організаціями. Прикладами співпраці є: консультації, роз'яснення питань щодо комунікаціі, надання потрібної інформації, нарощування військового потенціалу, економіки, освіти (Приклади військово-цивільного 
співробітництва, 2019). У 2004 р. Данія була однією із перших країн НАТО, яка розширила діяльність СІМІС щодо задоволення потреб місцевого населення. Такий підхід базувався на досвіді Афганістану, Балкан та Іраку i був взятий за основу щодо покращення діяльності CIMIC в НАТО та в інших країнах з метою вироблення багатостороннього підходу, що прискорить військову стабілізацію. У контексті «данської ініціативи» НАТО почало збільшувати свою взаємодію із Департаментом операцій щодо підтримання миру та Управлінням із координації гуманітарних питань ООН.

У Франції в середині 1990-х років набула актуальності концепція комплексного підходу, яка виникла від час афганської кризи. У 1991 р. Франція долучилась до миротворчих операцій під егідою Альянсу. У 1999 р. представники ЦВС Франції виконували завдання в Югославії. У лютому 2008 р. Франція звернулася до представників СІМІС НАТО з пропозицією зосередитись на комплексному підході щодо африканської та афганської криз. Цей підхід був погоджений у Бухаресті і впроваджений в Афганістані восени 2009 р. (Carnegie endowment, 2019) У концепції, запропонованій Францією, йшлося про прагматичне бачення діяльності CIMIC. Тобто йшлося про вдосконалення структури ЦВС таким чином, щоб суб'єкти змогли взаємодіяти та спілкуватися один 3 одним задля досягнення ефективних та швидких цілей та працювати у трьох узгоджених та скоординованих напрямах: управління, безпеки та економічного і соціального розвитку. Саме Франція запропонувала комплексний підхід НАТО в таких структурних напрямах: планування та проведення операції; актуалізація досвіду навчання та освіти; зміцнення співпраці із зовнішніми суб'єктами; повідомлення для громадськості; стабілізація та реконструкція. При тому залучення та участь громадськості передбачалася на всіх рівнях. Цей підхід спрямований на врегулювання кризи із виконанням всіх елементів, що дозволяють повернутися країні до стабільності (Carnegie endowment, 2019).

На початку XXI ст. збройні сили Німеччини взяли курс на забезпечення умов політичної безпеки, який передбачав відповідальність перед міжнародною спільнотою та гарантував загальну безпеку, що означало попередження впливу криз і конфліктів, запобігання та їх примирення. Завданням цього курсу було врегулювання будь-яких конфліктів та забезпечення національних інтересів держави. Саме 
тоді набула актуальності співпраця Бундесверу із державними та недержавними організаціями в самій країні та поза ії межами. На що було спрямовано й військово-цивільну співпрацю. Представником та ініціатором ЦВС у Німеччині $є$ військовий підрозділ Об'єднаних сили забезпечення. Цей орган виконує функцію сполучної ланки та рупора армії для підтримки компетентних органів цивільного захисту як в самій країні, так і у миротворчих місіях за межами держави. ЦВС бундесверу орієнтований на узгоджену взаємодію цивільних і військових осіб, яка під час планування військової операції орієнтована на населення. СIMIC Німеччини за кордоном спрямована на те, що здобувати інформацію у цивільному просторі, аналізувати та оцінювати іiі з метою визначення гуманітарного становища та намірів цивільного населення (Rietjens, 2008). Починаючи з 2013 р., Німеччина сформувала новий підхід до організації ЦВС. Це зумовлено отриманням досвіду у міжнародних операція $з$ підтримки миру та безпеки та орієнтацією на Доктрину HАTO CIMIC AJP-3.4.9. Отже, військово-цивільна співпраця бундесверу - це взаємодія військових із цивільним населенням для того, щоб сприяти виконанню військових завдань та досягти військових і цивільних цілей в рамках спільного забезпечення безпеки (Pakistan defence forum, 2019).

Норвезька структура СIMIC діє також відповідно до Доктрини AJP-9, а у стратегічну концепцію оборони Норвегії входять ряд документів, пов'язаних із цивільно-військовим співробітництвом. Саме цивільно-військове співробітництво втілене як функція у всю національно-військову діяльність. ЦВС Норвегії складається із групи підтримки (діяльність офіцерського корпусу офіцерів забезпечує діяльність для миротворчих місій, операцій ООН, ЄС, ОБСС) та волонтерів (зараховуються на індивідуальній основі). Норвегія має досвід розгортання підрозділів ЦВС з 2002 р. у миротворчих операціях у Боснії, Косові, Іраку та Афганістані (CCOE, 2016). Саме в Іраку та Афганістані Норвегія використовувала ЦВС як дієвий засіб боротьби з тероризмом. Військово-цивільна співпраця Норвегії охоплює завдання як всередині країни, так і поза іiі межами. Норвегія є однією із країн - засновниць Центру CIMIC, який розташований у Нідерландах (Тітко, 2017a).

Концепція CIMIC у межах нідерландської доктрини не стала винятком і також будується відповідно до Доктрини НАТО. ЦВС підтримує військову місію шляхом координації і співробітництва 
між військовими командирами і представниками цивільного населення. СІМІС у Нідерландах розуміється як співпраця між збройними силами та цивільними й урядовими організаціями. ЦВС розділяється на дві категорії: діяльність СІМІС, яка зосереджується на підтримці військових підрозділів цивільними інститутами (інфраструктурна організація, поставка товарів та послуг), та операції CIMIC, які належать до дій військових підрозділів на підтримку цивільних (допомога в реконструкції, ремонт інфраструктури, розмінування) (NATO, 2003). Такі заходи проводяться після врегулювання збройного конфлікту, мета яких полягає у збереженні суверенітету країни та попередженні повторного виникнення конфлікту. Поряд 3 тим доктрина СІМІС Нідерландів має свої особливості. ЦВС діє не лише за межами країни, але й на своїй території у формі операцій, що стосуються національної безпеки та внутрішніх стихійних лих (ССОE, 2016). Відповідно до Концепції оборони Нідерландів ЦВС охоплює шість середовищ: цивільна інфраструктура, економіка і комерція, цивільне адміністрування, гуманітарні питання, справи культури, економічний розвиток (Тітко, 2017c). Така діяльність спрямована на розробку проектів для місцевих громад.

Система ЦВС в Україні є дещо схожою із діяльністю СIMIC в Нідерландах. Адже військовослужбовці структури ЦВС виконують завдання на території своєї держави, що і робить українську систему CIMIC особливою. Власне, ідея щодо створення такої структури у складі Збройних Сил України виникла у 2005 р. Цей період характеризується активною участю в миротворчих операціях під егідою ООН (Кришталь, 2014). Пропозиції щодо введення в склад миротворчих контентів компонентів СIMIC пов'язувались iз необхідністю підвищення ефективності виконання завдань у міжнародних операціях, зокрема на території Іраку, Афганістану, Грузії, Югославії, Боснії і Герцеговини, Північної Македонії, Хорватії, Анголи, Косова, Демократичної Республіки Конго, Судану, Сьєрра-Леоне. Практична ж реалізація структури ЦВС почалась із ходом Антитерористичної операції на території Донецької та Луганської областей. 3 травня 2014 р. до другої половини 2016 р. розроблялась нормативно-правова база та поступово структури ЦВС почали створюватись на різних рівнях управління Збройних Сил України (Верховна Рада Украӥни, 2015). 
В українській структурі ЦВС взято за основу не лише Доктрину НАТО, але і враховано вітчизняний досвід на території нашої країни. Система ЦВС України є основною взаємодією між суспільством і Збройними Силами на лінії розмежування, в районах ведення бойових дій та відведення військ (Верховна Рада України, 1994). Адже взаємодія між місцевим населенням та військовими частинами (підрозділами) в зоні проведення ООС дозволяс останнім виконувати завдання за призначенням.

Висновки. Проаналізувавши історичний досвід створення та функціонування структури ЦВС армій провідних країн світу, варто зауважити, що діяльність ЦВС є необхідною та невід'ємною їх складовою, яка забезпечує успішне виконання воєнних операцій всередині самих країн, так і поза їх межами. Активізація наприкінці XX - на початку XXI ст. воєнно-політичних конфліктів «гібридного характеру» актуалізувала питання ефективного захисту та надання допомоги цивільному населенню, збереження його культурних та матеріальних цінностей та й самої інфраструктури держави, на території якої відбувається воєнний конфлікт. Керівництво розвинених країн світу, а також блоку НАТО усвідомило необхідність модернізації підходів до врегулювання воєнно-політичних конфліктів, що відобразилось у вдосконаленні нормативноправових актів, які стосувалися впровадження та діяльності структури СIMIC.

Характерним елементом діяльності органів CIMIC $є$ те, що їм притаманний цивільний структурний компонент, який спрямований як на співробітництво, так і на допомогу. Така діяльність $\epsilon$ новим підходом на шляху розвитку Збройних Сил. Адже, як свідчить досвід миротворчих операцій та ООС на території України, які б не були поставлені завдання, вони виконуються в умовах цивільного середовища і для їх вирішення саме діяльність структури ЦВС дає можливість краще зрозуміти всі особливості даного регіону, швидше врегулювати кризову ситуацію.

\section{Використані посилання}

Carnegie endowment, 2019. Civil-Military Cooperation in Afghanistan: The French Experience, [online] Available at: <https:// carnegieendowment.org/2014/12/19/civil-military-cooperation-inafghanistan-french-experience/hxoh> [Accessed 17 February 2019]. 
Civil-Military Cooperation Centre of Excellence, 2016. CIMIC Field Handbook. 4th edition. Netherlands: CCOE.

North Atlantic Treaty Organization, 2003. AJP-9 Nato Civil-Military Co-Operation (CIMIC) Doctrine, [online] Available at: <https:// www.nato.int/ims/docu/ajp-9.pdf> [Accessed 30 January 2019].

Pakistan defence forum, 2019. Pakistan defence, [online] Available at: <https://defence.pk/pdf/threads/civil-military-cooperation. 418248/ $>$ [Accessed 8 February 2019].

Rietjens, S. 2008. Managing Civil-military Cooperation: A 24/7 Joint Effort for Stability. Aldershot: Ashgate. ISB: 9780754672814.

Верховна Рада України, 1994. Про оборону Украӥни, [online] Київ: ВРУ. Доступно: https://zakon.rada.gov.ua/laws/show/1932-12 [Дата звернення 4 лютого 2019].

Верховна Рада України, 2015. Про затвердження Порядку надання гуманітарної та іншої допомоги населенню Донецької та Луганської областей, [online] Київ: ВРУ. Доступно: <https:// zakon.rada. gov.ua/laws/show/21-2015-\%D0\%BF> [Дата звернення 24 січня 2019].

Кришталь I. 2014. Цивільно-військове співробітництво Збройних Сил Украӥни, [online] Доступно: https://cimic.com.ua/ [Дата звернення 14 лютого 2019].

Лещенко О. 2017. Міжнародний досвід трансформації систем цивільного захисту в умовах сучасних воєнно-політичних конфліктів. Молодий вчений, [online] 8(48), С. 339-344. Доступно: <http://molodyvcheny.in.ua/files/journal/2017/8/75.pdf> [Дата звернення 11 лютого 2019].

Навчальні матеріали онлайн, 2010-2019. Приклади військовоицвільного співробітництва, [online] Доступно:

<https://pidruchniki.com/82961/politologiya/blok_prikladi_viyskovotsivilnogo_spivrobitnitstva> [Дата звернення 8 лютого 2019].

Національний університет оборони України імені Івана Черняховського, 2015. Цивільно-військове співробітництво за стандартами НАТО (civil-military cooperation). Київ: НУОУ ім. Івана Черняховського.

Тітко Е. 2017а. Доктринальні підходи до розуміння концепції цивільно-військового співробітництва (CIMIC) в оборонних стратегіях Хорватії, Данії, Норвегії та Нідерландів. Держсава і регіони. Серія: Право, [online] 1 (55), С. 125-131. Доступно: <http://www.law.stateandregions.zp.ua/archive/1_2017/26.pdf> [Дата звернення 4 лютого 2019]. 
Тітко Е. 2017b. Особливості правового регулювання діяльності CIMIC в організації північноатлантичного договору. Юридичний науковий електронний журнал, [online] 2, с. 158-161. Доступно: < http://www.lsej.org.ua/ 2_2017/44.pdf > [Дата звернення 1 лютого 2019].

Тітко Е. 2017c. Роль та значення місії ISAF в ісламській республіці Афганістан з урахуванням присутності сил CIMIC. Hayковий вісник міжнародного гуманітарного університету, [online] 25, С. 122-125. Доступно: <http://www.vestnikpravo. mgu. od.ua/archive/ juspradenc25/32.pdf> [Дата звернення 27 січня 2019].

Ткачук П., Красюк О., Кривизюк Л., Мокоївець В., Федоров О., Заболотнюк В., Бокачов С., Хаустов Д. 2018. Цивільно-військове співробітництво у сучасному збройному конфлікті. Львів: НАСВ. 140 с.

\section{References}

Carnegie endowment, 2019. Civil-Military Cooperation in Afghanistan: The French Experience, [online] Available at:<https:// carnegieendowment.org/2014/12/19/civil-military-cooperation-inafghanistan-french-experience/hxoh> [Accessed 17 February 2019] (eng).

Civil-Military Cooperation Centre of Excellence, 2016.CIMIC Field Handbook. 4th edition. Netherlands: CCOE (eng).

North Atlantic Treaty Organization, 2003. AJP-9 Nato Civil-Military Co-Operation (CIMIC) Doctrine, [online] Available at: <https: // www.nato.int/ims/docu/ajp-9.pdf> [Accessed 30 January 2019] (eng).

Pakistan defence forum, 2019. Pakistan defence, [online] Available at: <https://defence.pk/pdf/threads/civil-military-cooperation.418248/ $>$ [Accessed 8 February 2019] (eng).

Rietjens S. 2008. Managing Civil-military Cooperation: A 24/7 Joint Effort for Stability. Aldershot: Ashgate. ISB: 9780754672814 (eng).

Verkhovna Rada Of Ukraine, 1994. About the defense of Ukraine. [online] Kyiv: VRU. Available at: <https://zakon.rada.gov.ua/laws/show/ 1932-12> [Accessed 4 February 2019] (ukr).

Verkhovna Rada Of Ukraine, 2015. On Approving the Procedure for Providing Humanitarian and Other Assistance to the Population of Donetsk and Lugansk Oblasts, [online] Kyiv: VRU. Available at:〈https://zakon.rada.gov.ua/laws/show/21-2015-\%D0\%BF> [Accessed 24 January 2019] (ukr).

Kryshtal I. 2014. Civil-Military Cooperation of the Armed Forces of Ukraine, [online] Available at: <https://cimic.com.ua/> [Accessed 14 February 2019] (ukr). 
Leshchenko A. 2017. International experience of transformation of civil defense system in conditions of modern military-political conflicts. Young Scientist, [online] 8(48), pp.339-344. Available at: <http: // molodyvcheny.in.ua/files/journal/2017/8/75.pdf> [Accessed 11 February 2019] (ukr).

Training materials online, 2010-2019. Examples of military-civilian cooperation,[online] Available at:<https://idruchniki.com/82961/ politologiya/blok_prikladi_viyskovo-tsivilnogo_spivrobitnitstva> [Accessed 8 February 2019] (ukr).

National Defense University of Ukraine named after Ivan Chernyakhovsky, 2015. Civil-military cooperation on NATO standards (civil-military cooperation). Kyiv: NUOU named after Ivan Chernyakhovsky (ukr).

Titko E. 2017a. Doctrinal approaches to understanding the concept of civil-military cooperation (CIMIC) in the defense strategies of Croatia, Denmark, Norway and the Netherlands. State and regions. Series: Right, [online] 1 (55), pp. 125-131. Available at: <http:// www.law.stateandregions.zp.ua/archive/1_2017/26.pdf> [Accessed 4 February 2019] (ukr).

Titko E. 2017b. Peculiarities of legal regulation cimic activity of the north atlantic treaty organization. Legal scientific electronic journal, [online] 2, pp. 158-161. Available at: < http:/ /www.lsej.org.ua/ 2_2017/44.pdf > [Accessed 1 February 2019] (ukr).

Titko E. 2017c. The role and significante of the ISAF mission in the Islamic Republic of Afganistan taking into account the participation of CIMIC. Scientific Herald of the International Humanitarian University, [online] 25, pp. 122-125. Available at: < http://www.vestnikpravo.mgu.od.ua/archive/juspradenc25/32.pdf > [Accessed 27 January 2019] (ukr).

Tkachuk P., Krasyuk O., Krivizyuk L., Mukoishtev V., Fedorov O., Zabolotnyuk V., Bokachov S., Khustov D. 2018. Civil-military cooperation in the modern armed conflict. Lviv: NAA (ukr).

\section{Chobit I. \\ HISTORICAL EXPERIENCE OF LEADING COUNTRIES IN THE ESTABLISHMENT AND FUNCTIONING OF CIVIL- MILITARY COOPERATION STRUCTURES (CIMIC)}

The article briefly describes the history of the creation and functioning of Civil - Millitary Cooperation structures in the armies of the leading countries of the world. The concepts of civil-military cooperation in legal acts of defense strategy are justified Croatia, 
Denmark, France, Germany, USA, Norway, the Netherlands, Ukraine and also NATO. It is shown that it is necessary to understand the concept of SIMIS in the context of military activities aimed at the reconstruction and modernization of the armed forces in the direction of close ties with the civilian side. The role of the Center is shown as a mechanism that allows creating prerequisites for solving the tasks, providing appropriate assistance to the civilian population and the successful conclusion of an armed conflict.

Statement of the problem and the state of its research. In recent years, approaches to conflict resolution have changed and the legal requirements for their participants have been substantially revised. The international community is increasing the requirements for taking into account economic, social, religious, political, cultural and humanitarian factors when planning and conducting international peacekeeping operations. As international experience shows, the involvement of a wide range of civil institutions in the process of resolving an existing conflict contributes to the achievement of the common goal of resolving this armed conflict.

The relevance of the research center, primarily due to the armed conflict in the East of Ukraine. The CWS system in the Armed Forces of Ukraine is relatively new and is constantly being improved. Theoretical and practical interest is the very functioning of such structures in the armies of foreign states, their features and differences from the Ukrainian system of the Central Military Council.

Domestic researchers have already paid some attention to the problems of military-civilian cooperation, exploring information support, the system of training civil-military cooperation specialists, and civilianmilitary relations in the NATO countries. It is worth noting the articles of Yu. Kalagin, I. Koropatnik, S. Garkushi, N. Vasyukov, E. Titko, P. Tkachuk, V. Opryshko, I. Kuropatkin, A. Nozdrachev, A. Leshchenko, and also a number of collective works. However, the activity of the system of civil-military cooperation of the leading countries of the world is not fully investigated.

The purpose of the article is to analyze the regulation of the activities of the structure of civil-military cooperation of the leading countries of the world with an explanation of the basic principles and tasks, where special attention is paid to the element of communication with the civilian element.

Keywords: civil-military cooperation, doctrine, CIMIC, NATO, armed forces. 